\title{
Determinants of Current Account Balance in Six ASEAN Countries: A Panel Analysis Approach
}

\author{
Soo Xin $\operatorname{Lin}^{1} \&$ Jerome Kueh ${ }^{1}$ \\ ${ }^{1}$ Faculty of Economics and Business, Universiti Malaysia Sarawak, Malaysia \\ Correspondence: Jerome Kueh, Faculty of Economics and Business, Universiti Malaysia Sarawak, 94300 Kota \\ Samarahan, Sarawak, Malaysia.
}

Received: April 20, 2019

Accepted: June 19, 2019

Online Published: June 25, 2019

doi:10.5539/ijef.v11n7p129

URL: https://doi.org/10.5539/ijef.v11n7p129

\begin{abstract}
This paper aims to examine the potential determinants of current account balance, which has been an interesting research topic in analysis over the decade. The relationship between current account balance and several different variables, such as fiscal balance, public debt, real GDP, and age dependency ratio for old and young, are examined. In this paper, the selected time period is from 1990 to 2016, in order to include the financial crisis period in six ASEAN countries (Indonesia, Malaysia, Philippines, Singapore, Thailand, and Vietnam). To this end, the research is based on the estimation of panel unit root, panel cointegration, panel Vector Error-Correction Model (VECM) and panel Granger causality. The findings show that all variables are cointegrated in the long-run and there are also unidirectional and bidirectional causal relationships in the short-run.
\end{abstract}

Keywords: current account balance, fiscal balance, public debt, real GDP, age dependency ratio

\section{Introduction}

Over the decades until now, current account has been an interesting topic in research. According to Baharumshah, Ismail, and Lau (2009), current account balances (CAB) is often a subject of analysis. This is due to its important implication on nation's long-term economic progress. In words, the current account is an important indicator of economic health in every country. It is defined as the sum of trade balances, net current transfers and net foreign income. On the other hand, Makrevska-Disovska and Trpkova-Nestorovska (2016) mentioned that the balance of payment is a statistical report that concludes the economy transactions in the world, where the standard components of both accounts are current account, the capital and financial account.

Current account is classified as goods and services, income and current transfers (Makrevska-Disovska \& Trpkova-Nestorovska, 2016). Based on Park and Shin (2009), a country's CAB reflects the difference between its income and its expenditure. CA can be categorized into two aspects, which are positive and negative. When the nation is a net lender to the world, this is a situation of positive current account balance. However, negative current account balance symbolizes a net borrower from the rest of the world. Besides, a deficit country spends more than it is producing whereas the opposite is true for a surplus country; however, a surplus country saves more than it invests whereas the reverse is correct for a deficit country (Park \& Shin, 2009). Moreover, current account can also be referred to the nation's net foreign assets by total amount.

Furthermore, Asia is the largest mainland in the world in terms of both population and geographical area. According to Moreno (2007), Southeast Asia was experiencing a prompt development which is associated with large and persistent current account deficits in the 1990s. However, this situation lasted from 1990 to around 1996 where until the out-break of Asian Financial Crisis in 1997-1998. As example, in Malaysia, the current account deficit topmost at around 10 percent of GDP in 1995 and Thailand stood at a peak at 8 percent of GDP in 1996 (Moreno, 2007). These situation is comparable to Mexico in 1994 with 7 percent of GDP during the Peso Crisis. On the other hand, the current account deficits scenario reverse to become surplus after the crisis. For instance, this overturn was largely showed in Thailand. This may due to the sudden stop in capital inflows in 1990s.

The huge and persistent current account surplus in the aftermath of Asian Financial Crisis is a new phenomenon in ASEAN countries. In order to have more understanding on current account issues, several ASEAN countries are selected to undergo a research study: Indonesia, Malaysia, Philippines, Singapore, Thailand, and Vietnam. 
Current account sustainability is always an issue highlighted by government from then until today. All countries considered here are having an unstable current account, except Singapore which regularly preserves large surpluses (Moreno, 2007). In order to provide some perspectives on current accounts in the 6 ASEAN countries, Figures 1 exhibits the current account balance graphs from 1997 to 2016 for all the six ASEAN countries. This is aim to contribute insight on the different trends among six ASEAN countries.

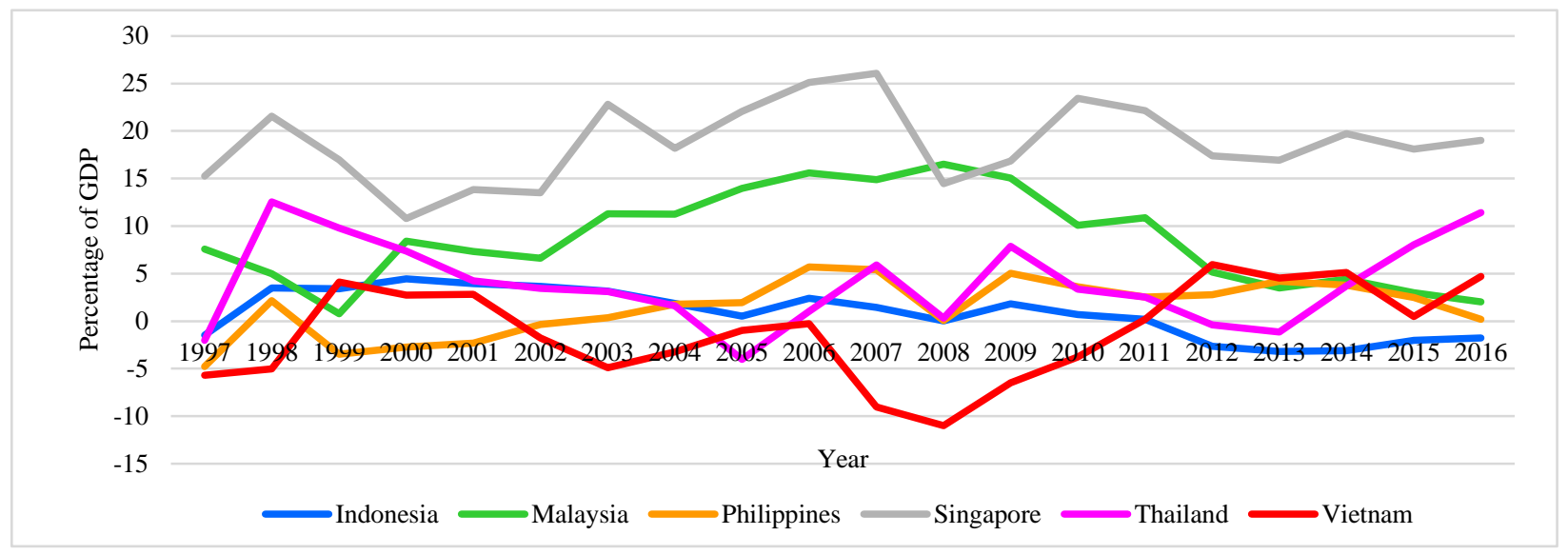

Figure 1. Current account balance of 6 ASEAN countries, 1997-2016

Source: International Monetary Fund, World Economic Outlook Database (April, 2017).

According to Bank Indonesia, the central bank of Indonesia, expects the country's current account deficit to increase to USD $\$ 4.8$ billion - or about 2.2 percent of gross domestic product (GDP) in 2016. In fact, Figure 1 shows a deficit of 1.75 percent of GDP in 2016. Although the deficit remains high and is estimated to go higher and higher, there is optimism that this increase is caused by rising imports of capital goods and raw materials. On the other hand, for Malaysia, Athukorala (2010) pointed out that in order to solve the problem of subprime mortgage in 2008, Malaysia was the first country to respond to the crisis with monetary expansion. Malaysia government had implemented two stimulus packages with direct cash injections (Athukorala, 2010). This leads export and also public investment to expand well. As a result, Malaysia economy begun to recover, and hence the current account surplus in peak value in year 2008. Nevertheless, the Philippines scores an all-time high of 1810.97 USD million in June 2014, after reaching a low of -1179.40 USD million in July 2008. This shows that the Philippines had put effort in their economy to ensure current account surplus rather than deficit.

Next, Singapore has regularly posted current account surpluses yearly, implying that Singapore has net profit with respect to the rest of the world. These surpluses have historically been redounded to positive trade balances, which is with goods account surpluses driving the current account balances since 1995. However, the trend on current account balance of Thailand as shown in Figure 1 exhibits a fluctuation of surpluses over the period. In 1998, Thailand posed a peak value of 12.53 percent of GDP on current account surpluses. However, the readings kept decreasing until it ended up in the deficit territory in 2005. As highlighted by Lauridsen (1998), the decreasing trend of current account balance is due to the excessive of investments, where many turned out to be too optimistic and unproductive. Most investments are based on money borrowed abroad. Then, as illustrated in Figure 1, after the Subprime Mortgage Crisis in 2008, current account balance of Vietnam continues to rise until it becomes surplus. This is a good sign for the economy of Vietnam. Earlier in 2007, the ASEAN Insights discussed on Vietnam, the manufacturing PMI climbed from 51.9 in January to 54.2 in February. This reflects the industrial manufacturing production of Vietnam is accelerating. Furthermore, Table 1 indicates the estimation for current account balance for ASEAN countries in the upcoming year, from 2017 to 2020. Among the selected research countries, Indonesia and the Philippines are forecasted to have current account deficits, whereas Malaysia, Singapore, Thailand, and Vietnam will propose a current account surplus. 
Table 1. Projected Current Account Balance (CAB) for ASEAN countries, 2017-2020

\begin{tabular}{ccccc}
\hline & \multicolumn{2}{c}{ CAB (Percentage of GDP) } \\
Country & $\mathbf{2 0 1 7}$ & $\mathbf{2 0 1 8}$ & $\mathbf{2 0 1 9}$ & $\mathbf{2 0 2 0}$ \\
\hline Brunei Darussalam & 8.323 & 4.300 & 14.012 & 18.326 \\
Cambodia & -8.539 & -8.477 & -8.453 & -8.416 \\
Indonesia & $\mathbf{- 1 . 9 0 0}$ & $\mathbf{- . 0 0 0}$ & $\mathbf{- 1 . 9 5 6}$ & $\mathbf{- 2 . 0 7 2}$ \\
Lao PDR & -18.849 & -19.176 & -19.377 & -18.833 \\
Malaysia & $\mathbf{1 . 7 8 5}$ & $\mathbf{1 . 8 2 0}$ & $\mathbf{1 . 8 4 5}$ & $\mathbf{1 . 8 2 2}$ \\
Myanmar & -6.636 & -6.657 & -6.607 & -6.543 \\
Philippines & $\mathbf{- 0 . 0 9 6}$ & $\mathbf{- 0 . 3 0 2}$ & $\mathbf{- 0 . 4 9 7}$ & $\mathbf{- 0 . 6 8 5}$ \\
Singapore & $\mathbf{2 0 . 0 9 6}$ & $\mathbf{1 9 . 1 6 1}$ & $\mathbf{1 8 . 7 4 4}$ & $\mathbf{1 8 . 3 4 0}$ \\
Thailand & $\mathbf{9 . 7 1 0}$ & $\mathbf{7 . 7 9 4}$ & $\mathbf{6 . 0 4 1}$ & $\mathbf{4 . 6 0 3}$ \\
Vietnam & $\mathbf{4 . 0 7 0}$ & $\mathbf{3 . 4 3 3}$ & $\mathbf{2 . 6 4 1}$ & $\mathbf{2 . 1 1 0}$ \\
\hline
\end{tabular}

Source: International Monetary Fund, World Economic Outlook Database (April, 2017).

Determining the potential determinants of current account balance in the six ASEAN countries is helpful to policy makers in ensuring appropriate policies adopted in solving the problems of deficits in current account and fiscal budgets. In the previous empirical analysis, the potential determinants are commonly done on interest rate, exchange rate, and trade, for example, Khan and Knight (1983) used real interest rates and REER; Calderon, Chong, and Loayza (2002) examined the potential determinants on REER, international interest rates, and trade; Neaime (2015) investigated on exchange rate. On the other hand, there are researchers include the variable of age dependency ratio in their models. However, the research are mostly on European countries, for example Khan and Knight (1983); Chinn and Prasad (2003); Aristovnik (2008); Brissimis, Hondrayiannis, Papazoglou, Tsaveas, and Vasardani (2013); Gehringer (2013); Lazar and Andreica (2013); Gossé and Serranito (2014); Bollano and Ibrahimaj (2015), where the research is less frequent been done on ASEAN countries. Hence, in this study, the age dependency ratio is included. Besides, this study also to inspect the relationship between variables in short run and long run.

According to Gehringer (2013), dependency ratio is crucial because it shows the ratio of economically inactive compared to economically active. Nevertheless, rising in the dependency ratio can bring the fiscal problems for government in decision making (Kim \& Lee, 2007). In addition, the differences in age structure across countries can help to explain the current account imbalances that emerged in this century (Gudmundsson \& Zoega, 2014). Gudmundsson and Zoega (2014) found that the current account surpluses of Singapore, Hong Kong, Korea, Thailand, Indonesia and Malaysia are much depreciated when the age structure is taken into account. In conjunction, Singapore, Thailand, Indonesia, and Malaysia are the involved research countries in this study. Moreover, Debelle and Faruqee (1996) mentioned that since the current account balance is equal to the excessive savings over investment, the population on age dependency can affect the balance of current accounts. Besides, Nieminen (2011) also stated that youth and old-age dependency ratio could have opposite effects on the current account balance. This is because the young people in the country will see the labor force growing in the future, where the long term capital investment is more attractive than those of aging countries population. In the other words, age dependency variable is important to include in this research model and at the end the empirical findings will exhibit how the age dependency affects current account balance over the period of study.

The research gaps of the study on determinants of current account balance are distinguished between former studies. As far concern, the only paper that done the research on Asia region which including of age dependency ratio as independent variable is Gudmundsson and Zoega (2014). People in different age dependency level will have different purchasing power. The purchasing power will lead to the difference occurs in current account. In other word, the young and old are treated as net consumers, whereas the others age group is considered as net savers, which that this is referring to the life-cycle hypothesis. With the inclusion of age dependency ratio, will enhance the policy makers a more informative references apply in six ASEAN countries.

\section{Literature Review}

The Twin Deficit hypothesis, the fiscal deficits are positively correlated to current account, where it has been the cornerstone for fiscal policy construction (Ganchev, Stavrova, \& Tsenkov, 2012). Following are several relevant literatures on the Twin Deficit hypothesis.

Chinn and Prasad (2003) studied the government budget as independent variable of current account balance. The research area covered 18 industrial and 71 developing countries from year 1971 to 1995 . Their analysis revealed 
that government budget balances appears to be positively correlated with current account balance. Next, Aristovnik (2008) raised the issue of current account determinants in 26 emerging countries of Eastern European and former Soviet Union, which including of 8 CEE countries, 6 SEE countries and 12 CIS countries. By estimating the final result, GMM estimator is applied. Government budget balance shows a positively significant relation to current account balance. As $1 \%$ rise in government budget balance will cause the percentage of current account balance to increase between 0.3 and 0.4. Early study by Baharumshah et al. (2009) examined the relevance of twin deficits hypothesis in ASEAN-5 countries (Indonesia, Malaysia, Philippines, Singapore, and Thailand). The investigation covered annual data from 1960 to 2003. The methodologies used are unit root test, cointegration test, VECM, and Granger causality. Empirical findings show that budget deficit exhibits a significant role in determining the current account deficit in Malaysia, Philippines, and Thailand. However, in Indonesia, current account deficits and budget deficits do not adapt the joint path. Moreover, Lau and Tang (2009) make another study on Cambodia by utilizing quarterly data, which is from 1996:Q1 to 2006:Q2. They summarized that there is bi-directional causality between budget deficit and external deficit. Besides, in short run, budget deficits cause the external deficits; in long run, both deficits indicate a relationship. Moreover, in a different study by Saysombath and Kyophilavong (2013) analyzed the current account balance of Laos. Their study involved recent year data, which is from 1980 to 2010. They used ARDL approach with unit root test, cointegraton test, VECM, and Granger causality test. Then, Saysombath and Kyophilavong (2013) discovered that budget balance and current account deficit are stationary in different forms. In addition, both variables retain in long and short runs, but bidirectional causality only exist in long run.

Nowadays, the relation among current account deficits and public debt have bring out a huge concern of scholars and policymakers, as the public debt will affect the current account balance (Neaime, 2015). Debelle and Faruqee (1996) presented a comprehensive review of current account balance determinants with 21 industrial countries involved in cross-sectional analysis, and 34 industrial and developing countries involved in panel analysis. This study is carried out in annual data basic with employing ECM and random effect model. In their panel analysis, the projected coefficient on budget surplus is 0.26 for low debt and 0.16 is for high debt countries, where same idea goes to that high public debt countries are more Ricardian. Then, for error-specification model analysis, public debt levels bring effect to current account balance in long run (Debelle \& Faruqee, 1996). However, for study by Calderon et al. (2002), they reported there is no statistically significant coefficient between external debt and current account deficit in 44 developing countries with panel analysis. On the other hand, the study of Aristovnik (2008) by adopting fixed effect model and GMM estimator, the result indicated that external debt and current account balance showed a positive and statistically significant relationship. Furthermore, Alam and Taib (2013) conducted their study based on 6 debt trap countries (DTC) and 8 non-debt trap countries (NDTC) by using unit root test, heteroscedasticity, and Granger causality. They proposed that there is positive relationship between public debt and current account deficit.

Real GDP reflects the level of development of a country (Brissimis et al., 2013). In other word, real GDP is used to measure the economic well-being of a country. Besides, Cavdar and Aydin (2015) also describes that real GDP demonstrates the sensitivity of the economy during financial crisis. According to an investigation by Calderon et al. (2002), real GDP is included as one of the independent variables in the study. The study is on 44 developing countries with time frame from 1966 to 1994, which is in the form of annual data with non-overlapping five years averages. It is an unbalanced panel data model that employed GMM estimator. Calderon et al. (2002) found that there is a negative and significant effect of real GDP to current account deficit. On the other hand, Osakwe and Verick (2007) identified the potential of real GDP on current account determinant. They found that when there is an increase in real GDP, will subsequently decrease the probability of having a high current account balance. The research area is on the 38 Sub-Saharan African countries. Furthermore, with the same objectives, Das (2016) conducted the research based on 27 high-income industrial, 32 emerging and 47 developing countries. The research year only cover from year 1980 to 2011 . The estimators that used by Das (2016) are difference GMM dynamic panel estimator and system GMM dynamic panel estimator. The study found that real GDP has a significant negative influence on current account balance, which implies the rises in real GDP will strengthen the developed country's higher income and hence leading more consumption expenditure causes in negative impact on current account balance.

Chinn and Prasad (2003) discovered that dependency ratio played an important role in defining the current account balance. The current account position of a country is affected by whether their populations' age grow faster or slower (Debelle \& Faruqee, 1996). Besides, the dependency ratios are more significant in illustrating medium-term rather than short-term variations in current account balances (Chinn \& Prasad, 2003). Chinn and Prasad (2003) analyzed their study based on 18 industrial and 71 developing countries from year 1971 to 1995. 
They adopted panel data with fixed effect model. In the findings, they concluded that higher relative dependency ratios are linked with smaller current account surpluses for some country groups. Moreover, the dependency ratios also seem to be negatively correlated with current account positions, especially youth dependency ratio in the developing countries has significant negative effect on current accounts when excluding African countries in the sample testing (Chinn \& Prasad, 2003). Next, Gruber and Kamin (2007) is also one of the researchers done the study on potential determinants towards current account balance. Authors discovered that the youth and elderly dependency ratios have effect to the current account balance. The study is examined on 61 countries from year 1982 to 2003 by employing fixed effect model. Continuously, Nieminen (2011) presented his work on 79 countries, where 30 are advanced economies and 49 are developing economies. Author presented the investigation by applying pooled OLS, Hausman test, random effect model and a robustness check. The result raised the conclusion on developing economies owned a stronger negative effect of dependency ratio on current account balance. More recently, Gossé and Serranito (2014) investigated the influential of dependency ratios on current account balance. The time frame overlaid year 1974 to 2009 in annual basic. Panel DOLS and VECM model are employed in the study. They indicated only when the temporal fixed effects are comprised in the regression, the dependency ratio will be significant with negative coefficient and significant at 10 percent level.

\section{Data and Methodology}

The main aim of this research is to investigate the determinants of CAB in six ASEAN countries, which are Indonesia, Malaysia, Philippines, Singapore, Thailand, and Vietnam that will affect the financial situation of each country from year 1990 to 2016, which covered 162 observations. In addition, this research also measures the trend of CAB in these six ASEAN countries related to the changes in fiscal balance, public debt, real GDP, and age dependency ratio for old and young. Moreover, this research is in a balanced panel data analysis. The dependent variable is current account balance $(\mathrm{CAB})$, whereas the independent variables are fiscal balance, public debt, real GDP, and age dependency ratio for old and young.

\section{Current Account Balance (CAB)}

$\mathrm{CAB}$ is the dependent variable in this research, where it is important guidance regarding previous planned on economy's performance (Aristovnik, 2008). Besides, CAB will also influence the economy and growth of a country. The CAB of countries are measured in percentage of GDP, where the data is retrieved from IMF, World Economic Outlook Database (2017).

\section{Fiscal Balance (FB)}

According to Baharumshah et al. (2009), FB implies on a nation's long term economic progress, where it is directly related to consumption and investment. The used indicator to access the FB is measuring the difference between tax revenues and expenditure of government. The data for tax revenues and expenses are obtained from IMF, World Economic Outlook Database (2017), which are measured in percentage of GDP.

\section{Public Debt (PD)}

Public debt is defined as the sum of present value of government spending and the initial debt level (Barro, 1979). In other word, also is explaining as how much money a country owes to lenders outside of itself, where include individuals, businesses and even governments. Besides, public debt also is the accumulation of yearly fiscal deficits. This is so lead by that annually the government spending exceeds the income from tax revenues. The data of public debt is obtained from IMF, World Economic Outlook Database (2017).

\section{$\underline{\text { Real GDP }(R G D P)}$}

Real GDP reflects the value of all services and goods which are produced by an economy in a given year. Real GDP is used to measure the economic well-being as real GDP will not be affected by changing in prices, and it only faced changes in the total amounts produced (Costanza, Hart, Posner, \& Talberth, 2009). The data of real GDP is retrieved from World Bank, World Development Indicator (2017), with unit of current USD.

\section{Age Dependency Ratio for Old and Young (ADRO/ARDY)}

Based on Chinn and Prasad (2003), age dependency ratio performs a very important part in determining the current account balance. ADR is categorized into two groups, there are old and young. According to Gruber and Kamin (2007), the ratio for the old is those people older than 64 and where the ratio for young is the number of young people at an age under 15, compared to the percentage number of people in working age. The related data for both groups are obtained from World Bank, World Development Indicator (2017), with unit of percentage of working-age population.

The main panel model specification of this research study is presented as follow. 


$$
C A B_{i t}=\alpha+\beta_{1} F B_{i t}+\beta_{2} P D_{i t}+\beta_{3} R G D P_{i t}+\beta_{4} A D R O_{i t}+\beta_{5} A D R Y_{i t}+\varepsilon_{i t}
$$

However, this balanced panel model is linear function with the degree of coefficients and variables are exactly equal to one. In order for the model to get the best fit model, the variables in the model is applied to log form. Hence, the equation applied with logarithm is expressed as below.

$$
L C A B_{i t}=\alpha+\beta_{1} L F B_{i t}+\beta_{2} L P D_{i t}+\beta_{3} L R G D P_{i t}+\beta_{4} L A D R O_{i t}+\beta_{5} L A D R Y_{i t}+\varepsilon_{i t}
$$

\section{Panel Unit Root Tests}

A unit root test is used to test for the stationary of a process that change with time. Stationary is essential in testing for variables to find out the validity of standard assumptions for asymptomatic analysis. The more unit roots a process has, the further away from stationary the process is, and the more differentiable the process' characteristic equation will be. A linear random function that is non-stationary will have at least one unit root. To get a stationary process from this, other roots of this characteristic equation that lies within the given absolute value will have to be differenced the number of times the unit roots the process has. In this study, Levin, Lin, and Chu (2002) and Im, Pesaran, and Shin (2003) panel unit root and stationary tests are adopted. This is to obtain conclusive evidence with regard to the order of integration of the series under investigation (Jayaraman \& Lau, 2008). Stationary of variables normally will happen at first difference, $I(1)$, seldom in level form. In order to determine whether the variables have or do not have unit root, the results in intercept and trend and intercept must be the same for either in level form or first difference. With this, the conclusion only can be made. The rejection rule for those tests are if the t-statistics value is greater than the significance value, $H_{0}$ is reject, which means that the variable is stationary. In other word, if the t-statistics value is smaller than the significance value, $H_{0}$ is do not reject, which means that the variable is non-stationary.

\section{Panel Cointegration Tests}

Panel cointegration test is normally used to investigate the long run equilibrium relationship between the variables. It is an implication of possibilities of having a cointegrating vector where the coefficient can be directly interpreted as long-term equilibrium. In cointegration test, the Pedroni $(1999,2001,2004)$ and Kao (1999) tests are used to test the long run relationship among the variables. Firstly, for cointegration testing in panel data, Pedroni $(1999,2001,2004)$ test is used to determine the cointegration between variables. The result is determined by taking the majority number on which the variables is reject or do not reject. After that, Kao (1999) test is carried out to support the finding results in Pedroni $(1999,2001,2004)$ test. In Pedroni test, there are total of seven panel cointegration tests, which are seven cointegration statistics (Pedroni, 1999). They can categorize into two sets, which are within dimension (panel tests) and between dimensions (group tests). In panel tests, there are $v$-statistics, $r h o$-statistics, $P P$-statistics, and $A D F$-statistics, while in group tests are $r h o$-statistics, $P P$-statistics, and $A D F$-statistics. Pedroni (1999) shows that under appropriate standardization based on the moments of vector of Brownian motion function, each of these statistics converges weakly to a standard normal distribution when both the $\mathrm{T}$ and $\mathrm{N}$ of the panel grow large. Jayaraman and Lau (2008) mentioned that for Kao (1999) test, cross-section specific intercepts and homogeneous coefficients on first-stage regressors are specified.

\section{Panel Fully Modified OLS (FMOLS) Estimates}

In this study, the econometric approach, fully modified OLS (FMOLS) is employed for the estimation. Phillips (1995) indicated that FMOLS regression was initially designed in work by Phillips and Hansen (1990), which is to provide optimal estimates of linear cointegrating regressions. Phillips and Hansen (1990) proposed an estimator that employs a semi-parametric correction to remove the issues caused by the long run correlation between the cointegrating equation and stochastic regressors innovations. Moreover, FMOLS estimator is asymptotically unbiased and has fully efficient mixture normal asymptotic allowing for standard Wald tests using asymptotic Chi-square statistical inference. On the other hand, Jayaraman and Lau (2008) also mentioned that panel group mean fully modified OLS (FMOLS) is used to obtain the long run estimates of the cointegrating relationship. The FMOLS comes out to be more reliable at extracting strong signal-to-noise ratios throughout the samples and is to be preferred. Moreover, Pedroni (2001) also found that FMOLS estimator is more robust and excellent in panels where there is considerable of heterogeneity. In addition, the FMOLS procedure accommodates the heterogeneity that is typically present both in the transitional serial correlation dynamics and in the long run cointegrating relationships (Jayaraman \& Lau, 2008).

\section{Empirical Findings}

The empirical tests that are covered under this model are panel unit root test, panel cointegration test, fully-modified OLS estimation (FMOLS), VECM, and panel Granger causality test. The empirical analyses of panel data in this study comprise the following steps. First, the stationary of data is examined by panel unit root 
tests. Under panel unit root tests, Levin et al. (2002) and Im et al. (2003) are adopted. Second, tests for cointegration among panel data were the panel cointegration test developed by Pedroni (1999, 2004), and Kao (1999). Next, is the estimation of long run on FMOLS and also DOLS. Fourth, proceed to VECM. Lastly, once the results of VECM is obtained, the panel Granger causality is employed to find out the short run causality among variables. While on the empirical results, the variables that emphasized are fiscal balance, public debt, real GDP, age dependency ratio for old, and age dependency ratio for young.

\subsection{Panel Unit Root Tests}

Im et al. (2003) allowed the between-group panel unit root tests that permit heterogeneity of the autoregressive root under the alternative. The null hypotheses of all unit root tests are to have a unit root in a series. Nevertheless, there is a great deal of research has been committed to the use of unit root tests. In other words, Levin et al. (2002) and Im et al. (2003) are the most popular approaches that used by researchers in unit root tests. Therefore, in my research study, I adopted these both approaches to examine the stationary of data. In addition, the ADF Fisher panel unit root test by Maddala and Wu (1999) also being adopted in this study at 10 percent of significant level.

Table 2. Levin, Lin, and Chu (LLC) panel unit root test results

\begin{tabular}{lcc}
\hline \multicolumn{2}{c}{$\begin{array}{c}\text { Test Statistics } \\
\text { LEVIN, LIN, AND CHU }\end{array}$} \\
\hline & \multicolumn{1}{c}{ Individual Intercept } & $\underline{\text { LEVEL }}$ \\
LCAB & $-1.1139(0.1327)$ & $-1.0116(0.1559)$ \\
LFB & $-2.6421(0.0041)^{*}$ & $-3.3286(0.0004)^{*}$ \\
LPD & $-15.3981(0.0000)^{*}$ & $-9.6784(0.0000)^{*}$ \\
LRGDP & $-1.0748(0.1412)$ & $-1.6223(0.0524)^{*}$ \\
LADRO & $1.3948(0.9185)$ & $-0.8572(0.1957)$ \\
LADRY & $-4.0286(0.0000)^{*}$ & $-3.5134(0.0002)^{*}$ \\
& & FIRST DIFFERENCE \\
$\Delta$ LCAB & $-9.0204(0.0000)^{*}$ & $-3.6017(0.0002)^{*}$ \\
$\Delta$ LFB & $-10.6245(0.0000)^{*}$ & $-7.9994(0.0000)^{*}$ \\
$\Delta$ LPD & $-8.1318(0.0000)^{*}$ & $-5.1504(0.0000)^{*}$ \\
$\Delta$ LRGDP & $-6.1989(0.0000)^{*}$ & $-5.2280(0.0000)^{*}$ \\
$\Delta$ LADRO & $0.4916(0.6885)$ & $1.5322(0.9373)$ \\
$\Delta$ LADRY & $-2.2868(0.0111)^{*}$ & $2.0420(0.9794)$ \\
\hline
\end{tabular}

Note. All variables are in logarithm form. LLC indicated the Levin et al. (2002) panel unit root and stationary tests. The LLC examines the null hypothesis of non-stationary of variables. The parenthesized values are the probability of rejection. Asterisks (*) indicates statistically significant at 10 percent level.

Table 3. Im, Pesaran, and Shin (IPS) panel unit root test results

\begin{tabular}{lcc}
\hline & \multicolumn{2}{c}{$\begin{array}{c}\text { Test Statistics } \\
\text { IM, PESARAN, AND SHIN }\end{array}$} \\
& \multicolumn{1}{c}{ Individual Intercept and Trend } \\
LCAB & $-1.2897(0.0986)^{*}$ & $-1.7570(0.0395)^{*}$ \\
LFB & $-2.4271(0.0076)^{*}$ & $-2.3810(0.0086)^{*}$ \\
LPD & $-8.3489(0.0000)^{*}$ & $-6.4176(0.0000)^{*}$ \\
LRGDP & $2.4331(0.9925)$ & $-1.7144(0.0432)^{*}$ \\
LADRO & $4.1973(1.0000)$ & $-1.3728(0.0849)^{*}$ \\
LADRY & $-0.2184(0.4136)$ & $-1.7592(0.0393)^{*}$ \\
& & FIRST DIFFERENCE \\
$\Delta$ LCAB & $-10.8101(0.0000)^{*}$ & $-9.1555(0.0000)^{*}$ \\
$\Delta$ LFB & $-10.7976(0.0000)^{*}$ & $-8.7068(0.0000)^{*}$ \\
$\Delta$ LPD & $-8.1029(0.0000)^{*}$ & $-6.1962(0.0000)^{*}$ \\
$\Delta$ LAGDP & $-5.5605(0.0000)^{*}$ & $-5.8448(0.0000)^{*}$ \\
$\Delta$ LADRY & $-2.0754(0.0190)^{*}$ & $0.0132(0.5052)$ \\
\hline
\end{tabular}

Note. All variables are in logarithm form. IPS indicated the Im et al. (2003) panel unit root and stationary tests. The IPS examines the null hypothesis of non-stationary of variables. The parenthesized values are the probability of rejection. Asterisks $(*)$ indicates statistically significant at 10 percent level. 
Table 4. ADF Fisher panel unit root test results

\begin{tabular}{|c|c|c|}
\hline & \multicolumn{2}{|c|}{$\begin{array}{l}\text { Test Statistics } \\
\text { ADF FISHER }\end{array}$} \\
\hline & $\underline{\text { Individual Intercept }}$ & dual Intercept and Trend \\
\hline & \multicolumn{2}{|c|}{ LEVEL } \\
\hline LCAB & $17.1248(0.1450)$ & $21.5226(0.0432)^{*}$ \\
\hline LFB & $24.1952(0.0191)^{*}$ & $24.6248(0.0167)^{*}$ \\
\hline LPD & $271.1880(0.0000)^{*}$ & $122.8480(0.0000)^{*}$ \\
\hline LRGDP & $7.6607(0.8111)$ & $21.4765(0.0438)^{*}$ \\
\hline LADRO & $5.2983(0.9473)$ & $23.5417(0.0235)^{*}$ \\
\hline \multirow[t]{2}{*}{ LADRY } & $13.8475(0.3106)$ & $24.3002(0.0185)^{*}$ \\
\hline & \multicolumn{2}{|c|}{ FIRST DIFFERENCE } \\
\hline$\triangle \mathrm{LCAB}$ & $105.7250(0.0000)^{*}$ & $82.5221(0.0000) *$ \\
\hline$\Delta \mathbf{L F B}$ & $107.1160(0.0000)^{*}$ & $77.4697(0.0000)^{*}$ \\
\hline$\Delta \mathbf{L P D}$ & $78.8677(0.0000)^{*}$ & $56.2207(0.0000)^{*}$ \\
\hline$\triangle$ LRGDP & $52.0742(0.0000)^{*}$ & $51.8073(0.0000)^{*}$ \\
\hline$\triangle$ LADRO & $21.7664(0.0402)^{*}$ & $12.9551(0.3723)$ \\
\hline$\triangle$ LADRY & $20.0568(0.0660)^{*}$ & $2.4705(0.9980)$ \\
\hline
\end{tabular}

Note. All variables are in logarithm form. ADF Fisher indicated the Maddala and Wu (1999) panel unit root and stationary tests. The ADF examines the null hypothesis of non-stationary of variables. The parenthesized values are the probability of rejection. Asterisks $(*)$ indicates statistically significant at 10 percent level.

According to Levin et al. (2002) and Im et al. (2003), the null hypothesis for both approaches are the same, which is unit root exists. Based on the theory, all the variables should be stationary, where there is no unit root exist. When the variables are stationary, just can proceed to cointegration test. In that three types of panel unit root tests, can be separated into two dimension, which are individual intercept and individual intercept with trend.

Table 2, 3, and 4 tabulated the results of the LLC, IPS, and ADF Fisher panel unit root tests. According to the results above, summarized that almost the series of these variables in LLC, IPS, and ADF Fisher are of an I(1) process. However, for ADRO and ADRY are of an I(0) process. In LLC, IPS and ADF Fisher tests, majority of the variables are greater than the significant level of 5 percent in level form, $I(0)$ of both individual intercept and individual intercept and trend, which means that variables are non-stationary and unit root exist. Therefore, proceed to first difference, $I(1)$. Besides, for ADRO and ADRY variables, the probability value is relatively smaller than significant level (10 percent) at level form. Hence, these both variables are said to be stationary at $I(0)$ process. Next, when proceed to first difference I(1), for LLC, IPS and ADF Fisher tests, almost all the probability of variables are smaller than the significant level, hence the null hypothesis of unit root exists is rejected. Therefore, concluded that majority variables are stationary in $I(1)$, which unit root does not exist in those three panel unit root tests. As conclude, all series of variables have no unit root and in other word is stationary.

\subsection{Panel Cointegration Tests}

As overall, there are Pedroni $(1999,2001,2004)$ and Kao (1999) panel cointegration test. For Pedroni (1999, 2001, 2004) panel cointegration test, it can be separated into two types, which are without trend and with trend. Besides, there are also two sets of tests recommended in, within dimension approach and between dimension approach. In within dimension approach, there are four types of test statistics, v-statictics, rho-statistics, $P P$-statistics, and $A D F$-statistics. These statistics are basically for different country from pooled regression on coefficients unit root test estimation residuals. Besides, common time factors and heterogeneity across country are considered too. Whereas, for between dimension approach, included group rho-statistics, $P P$-statistics, and $A D F$-statistics. These statistics are based on the averages of individual autoregressive coefficients associated with the unit root tests of the residuals for each country in the panel. 
Table 5. Panel cointegration test results

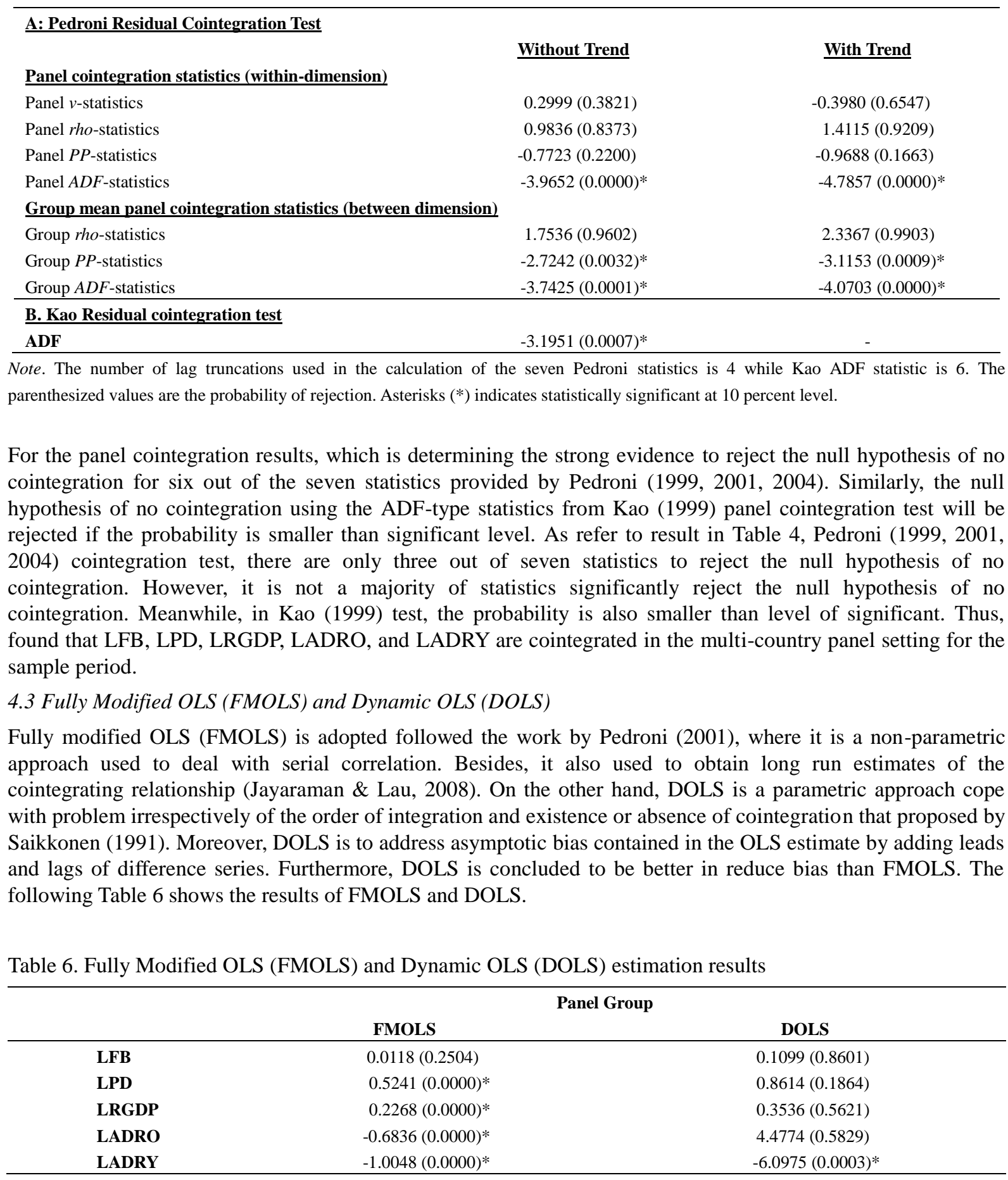

Note. All variables are in logarithm form. The values in parentheses are t-statistics. Asterisk $\left(^{*}\right)$ shows significance at 10 percent level.

In the equation with $\mathrm{CAB}$ as dependent variable, FMOLS estimation shows the result that LPD, LADRO, LADRY, and LRGDP are significant to LCAB. Where LPD and LRGDP denote positive significant relationship, while LADRO and LADRY indicate a negative significant. However, LFB shows a positive but insignificant to LCAB. On the other hand, in DOLS estimation only LADRY shows a negative significant to LCAB, while the other independent variables denote positive insignificant in the estimation. In addition, the estimate of $\mathrm{CAB}$ with respect to ADRY in DOLS estimation is -6.0975, indicating one percent decrease in ADRY leads to 6.01 percent drop in CAB. The result is same to the past studies of Chinn and Prasad (2003) and Nieminen (2011).

In addition, in order to obtain high accuracy and results that tally with previous studies, a dummy variable (D1) 
is included in the model, where D1 denotes the ASEAN financial crisis that happened from 1997 to 1999 . The model with D1 is estimated with FMOLS and DOLS, and then the results are tabulated in Table 7.

Table 7. Fully Modified OLS (FMOLS) and Dynamic OLS (DOLS) estimation results

\begin{tabular}{lcc}
\hline & & Panel Group \\
\cline { 2 - 3 } LFB & FMOLS & DOLS \\
LPD & $0.4507(0.0000)^{*}$ & $2.7461(0.0000)^{*}$ \\
LRGDP & $0.5211(0.0000)^{*}$ & $1.2698(0.0000)^{*}$ \\
LADRO & $0.2257(0.0000)^{*}$ & $2.0876(0.0000)^{*}$ \\
LADRY & $-0.6869(0.0000)^{*}$ & $-1.2301(0.0000)^{*}$ \\
D1 & $-1.0401(0.0000)^{*}$ & $-16.1812(0.0000)^{*}$ \\
& $0.2186(0.0000)^{*}$ & $3.3976(0.0000)^{*}$ \\
\hline
\end{tabular}

Note. All variables are in logarithm form. The values in parentheses are $t$-statistics. Asterisk $\left.{ }^{*}\right)$ shows significance at 10 percent level.

The results in Table 7 included dummy variables (D1) indicates that in FMOLS and DOLS estimations all independent variables are significant to LCAB. Meanwhile, LFB, LPD, LRGDP, and D1 denote positive significant to LCAB in both estimation, whereas only LADRO and LADRY indicate negative but significant to LCAB. The estimation results of both estimations are similar with the research of previous studies. Since the variables are in $\log$ forms, values of the estimated coefficients denote the elasticity magnitudes: one percent decrease in ADRO leads to 0.69 percent decrease in $\mathrm{CAB}$, where one percent reduce in ADRY also will leads to 1.04 percent decline in $\mathrm{CAB}$. The results for ADRO and ADRY in both estimations are negative significant to $\mathrm{CAB}$ which are tally and match the findings of past studies, for examples, Debelle and Faruqee (1996), Chinn and Prasad (2003), Aristovnik (2008), Kim and Lee (2008), Nieminen (2011), and Gossé and Serranito (2014). They research findings stated that age dependency ratio has negative and significant relationship with CAB. In their study, they stand on the view that dependency ratio and CAB are negatively significant. This may due to young age group does not have work and old age group is retired while they own their retired schemes and savings as their financial support. Hence, when there is decrease in the old and young dependency ratios, will cause the savings amount to reduce too. Therefore, leads the current account to deficit.

Furthermore, according to the theory of twin deficit hypothesis, the expected sign of FB should be in positive in both estimations. Meanwhile the results of both estimations show that FB is positive significant to CAB. The estimate coefficients of $\mathrm{CAB}$ with respect to $\mathrm{FB}$ in FMOLS estimation is 0.4507 , indicating one percent increase in FB leads to 0.45 percent rise in CAB. While in DOLS estimation the estimate coefficients of CAB is 2.7461 , indicating one percent increase in FB brings to 2.75 percent rises in $\mathrm{CAB}$. The results are supported by previous studies that raised by Chinn and Prasad (2003); Chinn and Ito (2007); Aristovnik (2008); Baharumshah et al. (2009); Bagnai (2010); Kalou and Paleologou (2012); Gehringer (2013); Bollano and Ibrahimaj (2015). In addition, RGDP also indicates statistically significant positive relationship with $\mathrm{CAB}$, where the elasticity estimate coefficient of CAB with respect to RGDP in FMOLS estimation is 0.2257, where in DOLS estimation is 2.0876. This contributes as RGDP rises by one percent, will causes to the increase in CAB by 0.23 and 2.09 percent. This finding also shown in the studies of Brissimis et al. (2012); Mwangi (2014); Cavdar and Aydin (2015). They mentioned that RGDP is consistent with theoretical expected to expand CAB when a rise in GDP growth. Furthermore, PD shows that it is positive significant with $\mathrm{CAB}$ in both estimation, where the coefficient in FMOLS estimation is 0.5211 and in DOLS estimation is 1.2698. This denotes the public debt will affect CAB in those respective countries, where it is the determinants of CAB in the six ASEAN countries when adopting FMOLS and DOLS estimation. There are studies that indicate the same result that PD is positive significant to CAB, it is from the studies of Debelle and Faruqee (1996); Alam and Taib (2013); Lazar and Andreica (2013).

\subsection{Panel Granger Causality}

The empirical results for panel Granger causality are summarized as follows in Table 8 and Table 9. First, the coefficient of the error correction term (ECT) is statistically significant, indicating there is long run causality relationship running from $\mathrm{FB}, \mathrm{PD}, \mathrm{RGDP}, \mathrm{ADRO}$ and $\mathrm{ADRY}$ to $\mathrm{CAB}$. Second, there appears to be a significant short run causal relationship running from $\mathrm{FB}, \mathrm{PD}, \mathrm{RGDP}, \mathrm{ADRO}$ and $\mathrm{ADRY}$ to $\mathrm{CAB}$ based on the Chi-square statistics of the coefficients of the variables. 
Table 8. VECM result

\begin{tabular}{|c|c|c|}
\hline \multirow[t]{2}{*}{ Dependent Variables } & \multicolumn{2}{|c|}{ ECT } \\
\hline & Coefficient & $t$-ratio \\
\hline$\triangle \mathrm{LCAB}$ & $-0.2881^{*}$ & -4.3470 \\
\hline$\Delta \mathbf{L F B}$ & $-0.1070^{*}$ & -1.7629 \\
\hline$\Delta \mathbf{L P D}$ & 0.0910 & 2.2110 \\
\hline$\triangle$ LRGDP & 0.0142 & 2.3908 \\
\hline$\Delta$ LADRO & -0.0008 & -0.6643 \\
\hline$\Delta$ LADRY & $-0.0031^{*}$ & -3.3325 \\
\hline
\end{tabular}

Note. All variables are in logarithm form. Parenthesized value shows the statistically significant value of ECT. $\Delta$ is the first different operator. Estimations are based on the balanced data for 1990-2016 and 6 ASEAN countries. Countries ( $N=6, T=27)$ with two lags. Asterisk (*) shows significance at 10 percent level.

Moreover, there is short run causality running from PD to CAB, FB to PD, FB to RGDP, RGDP to PD, ADRO to RGDP, and RGDP to ADRY. These causalities only are unidirectional causality between each. On the other hand, CAB to RGDP shows a bidirectional causality between each other. Besides, there are three variables appear to be the initial receiver of any exogenous shocks that disturb the equilibrium of the panel system under the 10 percent of significant level, which are LCAB, LFB, and LADRY. This is evidenced in the statistically significant ECT in the LCAB, LFB, and LADRY equations in the panel system. For LCAB, the coefficient of ECT in the equation is 0.2881 , indicating that about 28.81 percent of the adjustment is needed to complete in a year. This means that $\mathrm{CAB}$ needs approximately 3.47 years to reach long run equilibrium from the estimated results. While for LFB, the coefficient of ECT in the equation is 0.1070 , implying that is around 10.7 percent of the adjustment is needed in a year. This marks FB requires 9.35 years to reach long run equilibrium according to the estimated results. Whereas the coefficient of ECT in the equation of LADRY is 0.0031, which is 0.31 percent of the adjustment. This denotes that ADRY demands roughly 322.58 years to reach long run equilibrium based on the predicted outcome. Next, the directions of causal relationship obtained from Table 9 are graphically illustrated in Figure 2.

Table 9. Panel Granger Causality results

\begin{tabular}{ccccccc}
\hline $\begin{array}{c}\text { Dependent } \\
\text { Variable }\end{array}$ & $\Delta \mathbf{L C A B}$ & $\Delta \mathbf{L F B}$ & $\Delta$ LPD & $\Delta$ LRGDP & $\Delta$ LADRO & $\Delta$ LADRY \\
\hline & & & \multicolumn{7}{c}{$\boldsymbol{x}^{2}$-statistics $(p$-value $)$} \\
$\Delta$ LCAB & - & $0.0865(0.9577)$ & $4.9803(0.0829)^{*}$ & $12.0171(0.0025)^{*}$ & $0.2971(0.8619)$ & $3.8710(0.1444)$ \\
$\Delta \mathbf{L F B}$ & $2.7642(0.2510)$ & - & $0.1486(0.9284)$ & $2.5482(0.2797)$ & $0.8547(0.6522)$ & $0.9030(0.6367)$ \\
$\Delta \mathbf{L P D}$ & $1.1651(0.5585)$ & $9.7277(0.0077)^{*}$ & - & $31.7450(0.0000)^{*}$ & $1.8762(0.3914)$ & $0.9321(0.6275)$ \\
$\Delta$ LRGDP & $5.6832(0.0583)^{*}$ & $5.2947(0.0708)^{*}$ & $3.7602(0.1526)$ & - & $1.7485(0.0931)^{*}$ & $1.3153(0.5181)$ \\
$\Delta$ LADRO & $2.3156(0.3142)$ & $2.2251(0.3287)$ & $1.3580(0.5071)$ & $7.5297(0.0232)^{*}$ & - & $2.5773(0.2756)$ \\
$\Delta$ LADRY & $4.5694(0.1018)$ & $0.9933(0.6086)$ & $0.1647(0.9209)$ & $5.8991(0.0524)^{*}$ & $0.8559(0.6518)$ & - \\
\hline
\end{tabular}

Note. All variables are in logarithm form. Parenthesized values are the probability of rejection of Granger non-causality. $\Delta$ is the first different operator. Estimations are based on the balanced data for 1990-2016 and 6 ASEAN countries. Countries (N=6, T=27) with two lags. Asterisk (*) shows significance at 10 percent level.

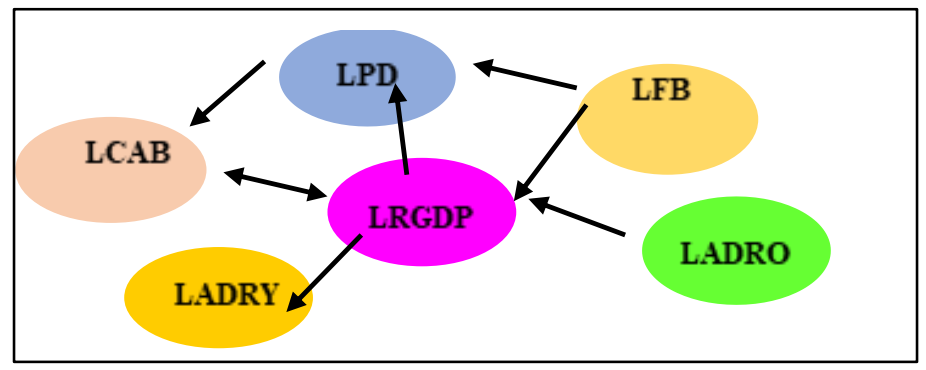

Figure 2. Direction of causal relationship

Note. $\mathrm{LPD} \rightarrow \mathrm{LCAB}, \mathrm{LFB} \rightarrow \mathrm{LPD}, \mathrm{LFB} \rightarrow \mathrm{LRGDP}, \mathrm{LRGDP} \rightarrow \mathrm{LPD}, \mathrm{LADRO} \rightarrow$ LRGDP, and LRGDP $\rightarrow$ LADRY imply unidirectional causality, while $\mathrm{LCAB} \leftrightarrow$ LRGDP implies bidirectional causality. 


\section{Conclusion}

The objective of this study is to identify the determinants of current account balance in the six ASEAN countries, which are Indonesia, Malaysia, Philippines, Singapore, Thailand, and Vietnam by applying a panel data analysis approach from 1990 to 2016. The determinants of current account balance are fiscal balance, public debt, real GDP, age dependency ratio for old and age dependency ratio for young. In the three panel unit root tests, majority series of variables are stationary in $I(1)$, which unit root does not exist. In other words, the findings showed that all series of variables are stationary with order of integration of first. Next, panel cointegration tests reveal that LFB, LPD, LRGDP, LADRO, and LADRY are cointegrated in the multi-country panel setting for the sample period. This is because the results fulfill the rejection rule in panel cointegration tests where the null hypothesis of no cointegration will be rejected when there is majority of statistics act significantly. Furthermore, based on the FMOLS and DOLS estimation results, when excluding the dummy variable (D1) that represented the ASEAN financial crisis that happened in 1997 to 1999, found that most of the variables are insignificant to LCAB. However, when including of D1 variable in the model, the results obtained indicate that all variables are significant to LCAB, whereby only LADRO and LADRY are negatively significant influence LCAB, while LFB, LPD, LRGDP, D1 are positively significant to LCAB. Hence, both estimations imply that the including of D1 reflect the variables are significant to be the determinants of CAB. Moreover, the results for LADRO and LADRY in both estimations are negative significant to LCAB which are tally and match the findings of past studies, for examples, Debelle and Faruqee (1996), Chinn and Prasad (2003), Aristovnik (2008), Kim and Lee (2008), Nieminen (2011), and Gossé and Serranito (2014). In their study, they stand on the view that dependency ratio and $\mathrm{CAB}$ are negatively significant. This may due to young age group does not have work and old age group is retired while they own their retired schemes and savings as their financial support. Hence, when there is decrease in the old and young dependency ratio, will cause the savings amount to reduce too. Therefore, leads the current account to deficit. Furthermore, the panel Granger causality results shows that all variables have causality linkage between each other in short run. There is unidirectional causality linkage runs from LPD to LCAB, LFB to LPD, LFB to LRGDP, LRGDP to LPD, LADRO to LRGDP, and LRGDP to LADRY. Moreover, there is also bidirectional causality linkage between CAB and RGDP. In other words, there are six unidirectional causality linkage and only one bidirectional causality linkage as well occur in short run. In advance, this paper found and presented important evidence that age dependency ratio is significant to the CAB in developing countries. The findings are consistent with the finding from previous literature on this same topic. Gudmundsson and Zoega (2014) mentioned that age dependency with different age structure can affect the current account imbalances. The reason is people in different age dependency level will have different purchasing power, where the purchasing power will lead to the difference occurs in current account. As referring to previous studies, age dependency ratio variable is seldom being included. As far as concern, the only paper that done the research on Asia region which including age dependency ratio is Gudmundsson and Zoega (2014). Besides, Chinn and Prasad (2003) also highlighted the importance of demographic profiles in determining CAB and therefore include age dependency ratio in examining the factor affecting $\mathrm{CAB}$. This will enhance a more informative and better references to policymakers in managing the CAB of country. Lastly, since this study is one of the few studies address the age dependency ratio in ASEAN countries, there remains much to extend and improve this presented analysis. Furthermore, Aristovnik (2007) suggested that in order to deepen the examining of $\mathrm{CAB}$ determinants, it is worthwhile to undertake a more detailed analysis at country level, suggested that time series analysis, where the particular country-specific characteristics can be taken into account. Cecchetti, Mohanty, and Zampolli (2011) also mentioned that ageing will definitely boost the public debt to a higher level in future decades. The raises of public debt and population age will sharply slow down economic growth, and even brings huge impact to fiscal problems. Therefore, also suggest that further research on public debt and age dependency ratios can be carried out to examine their relationship in affecting the CAB.

\section{References}

Alam, N., \& Taib, F. M. (2013). An investigation of the relationship of external public debt with budget deficit, current account deficit, and exchange rate depreciation in debt trap and non-debt trap countries. European Scientific Journal, 9(22), 144-158.

Aristovnik, A. (2007). Short and medium-term determinants of current account balances in Middle East and North Africa countries (William Davidson Institute working paper No. 862). Slovenia: University of Ljubljana. https://doi.org/10.2139/ssrn.988171

Aristovnik, A. (2008). Short-term determinants of current account deficits: Evidence from Eastern Europe and the former Soviet Union. Eastern European Economics, 46(1), 24-42. https://doi.org/10.2753/EEE0012-8775460102 
Athukorala, P. C. (2010). Malaysian economy in three crisis (The ANU working paper No. 2010/12). Canberra, Australia: The Australian National University.

Bagnai, A. (2010). Twin deficits in CEEC economies: Evidence from panel unit root tests. Economics Bulletin, 30(2), 1-9.

Baharumshah, A. Z., Ismail, H., \& Lau, E. (2009). Twin deficits hypothesis and capital mobility: The ASEAN-5 perspective. Jurnal Pengurusan. 29, 15-32.

Barro, R. J. (1979). On the determination of the public debt. Journal of Political Economy, 87(5), 940-971. https://doi.org/10.1086/260807

Bollano, J., \& Ibrahimaj, D. (2015). Current account determinants in Central Eastern European countries (Graduate Institute of International and Development Studies working paper No. 22/2015). Switzerland: Bank of Albania.

Brissimis, S. N., Hondroyiannis, G., Papazoglou, C., Tsaveas, N. T., \& Vasardani, M. A. (2013). The determinants of current account imbalances in the Euro area: A panel estimation approach. Economic Change and Restructuring, 46(3), 299-319. https://doi.org/10.1007/s10644-012-9129-0

Calderon, C. A., Chong, A., \& Loayza, N. V. (2002). Determinants of current account deficits in developing countries. Contributions to Macroeconomics, 2(1), 1-31. https://doi.org/10.2202/1534-6005.1021

Cavdar, S. C., \& Aydin, A. D. (2015). A different perspective for current account deficit issue on some OECD member countries: A binary panel logit approach. Research in World Economy, 6(3), 14-22. https://doi.org/10.5430/rwe.v6n3p14

Cecchetti, S. G., Mohanty, M. S., \& Zampolli, F. (2011). The real effects of debt (BIS Working Papers No. 352). Basel, Switzerland: Bank for International Settlements Communications.

Chin, M. D., \& Prasad, E. S. (2003). Medium-term determinants of current accounts in industrial and developing countries: An empirical exploration. Journal of International Economics, 59(1), 47-76. https://doi.org/10.1016/S0022-1996(02)00089-2

Chinn, M. D., \& Ito, H. (2007). Current account balances, financial development and institutions: Assaying the world "saving glut". Journal of International Money and Finance, 26(4), 546-569. https://doi.org/10.1016/j.jimonfin.2007.03.006

Costanza, R., Hart, M., Posner, S., \& Talberth, J. (2009). Beyond GDP: The need for new measures of progress (The Pardee Papers No. 4). Boston, Massachusetts: Boston University.

Das, D. K. (2016). Determinants of current account imbalance in the global economy: A dynamic panel analysis. Journal of Economic Structures, 5(8), 1-24. https://doi.org/10.1186/s40008-016-0039-6

Debelle, G., \& Faruqee, H. (1996). What determines the current account? A cross-sectional and panel approach (IMF working paper NO. 58). US: International Monetary Fund (IMF). https://doi.org/10.5089/9781451966701.001

Ganchev, G. T., Stavrova, E., \& Tsenkov, V. (2012). Testing the twin deficit hypothesis: The case of central and Eastern European countries. International Journal of Contemporary Economics and Administrative Sciences, 2(1), 1-21.

Gehringer, A. (2013). Another look at the determinants of current account imbalances in the European Union: An empirical assessment (FIW working paper No. 105). FIW. https://doi.org/10.2139/ssrn.2159132

Ghosh, A., \& Ramakrishnan, U. (2012). Current account deficits: Is there a problem? International Monetary Fund (IMF).

Gruber, J. W., \& Kamin, S. B. (2007). Explaining the global pattern of current account imbalance. Journal of International Money and Finance, 26(4), 500-522. https://doi.org/10.1016/j.jimonfin.2007.03.003

Gudmundsson, G. S., \& Zoega, G. (2014). Age structure and the current account. Economics Letters, 123(2), 183-186. https://doi.org/10.1016/j.econlet.2014.02.001

Holtz-Eakin. D., Newey. W., \& Rosen, H. (1989). The revenues-expenditure nexus: Evidence from local government data. International Economic Review, 30, 415-429. https://doi.org/10.2307/2526655

Holtz-Eakin. D., Newey. W., \& Rosen. H. (1988). Estimating vector autoregressions with panel data. Econometrica, 56(6), 1371-1395. https://doi.org/10.2307/1913103 
Im, K. S., Pesaran, M. H., \& Shin, Y. (1997). Testing for unit roots in heterogenous panel. DAE, Working Paper 9526, University of Cambridge.

Im, K. S., Pesaran, M. H., \& Shin, Y. (2003). Testing for unit roots in heterogeneous panels. Journal of Econometrics, 115(1), 53-74. https://doi.org/10.1016/S0304-4076(03)00092-7

IMF. (2017a). World economic outlook. Data center, current account balance, annual, 1990-2016.

IMF. (2017b). World economic outlook. Data center, government debt, annual, 1990-2016.

Jayaraman, T. K., \& Lau, E. (2008). Causal relationships between current account imbalances and budget deficits in Pacific Island countries: A panel cointegration survey. Fiji Island: University of the South Pacific.

Kalou, S., \& Paleologou, S. M. (2012). The twin deficits hypothesis: Revisiting an EMU country. Journal of Policy Modelling, 34(2), 230-241. https://doi.org/10.1016/j.jpolmod.2011.06.002

Kao, C. (1999). Spurious regression and residual-based tests for cointegration in panel data. Journal of Econometrics, 90(1), 1-44. https://doi.org/10.1016/S0304-4076(98)00023-2

Khan, M. S., \& Knight, M. D. (1983). Determinants of current account balances of non-oil developing countries in the 1970s. Staff Papers, 30(4), 819-842. https://doi.org/10.2307/3866787

Kim, S., \& Lee, J. W. (2007). Demographic changes, saving, and current account in East Asia. Asia Economic Papers, 6(2), 22-53. https://doi.org/10.1162/asep.2007.6.2.22

Kurt, E., \& Ozkiper, O. (2015). Determinants of current account balance: An empirical analysis for developing countries (Master's thesis). Politecnoci Di Milano, Italy.

Lau, E., \& Tang, T. C. (2009). Twin deficits in Cambodia: An empirical study. Economics Bulletin, 29(4), 2783-2794.

Lauridsen, L. S. (1998). The financial crisis in Thailand: Causes, conduct and consequences? World Development, 26(8), 1575-1591. https://doi.org/10.1016/S0305-750X(98)00069-2

Lazar, I., \& Andreica, M. E. (2013). Current account balance, private debt and Euro area sovereign debt crisis: A comparison of North and South. Romanian Journal of Economics, 37(2), 46.

Levin, A., \& Lin, C. F. (1993). Unit root test in panel data: New results. University of California at San Diego, Discussion Paper, pp. 93-56.

Levin, A., Lin, C. F., \& Chu, C. S. J. (2002). Unit root tests in panel data: Asymptotic and finite-sample properties. Journal of Econometrics, 108(1), 1-24. https://doi.org/10.1016/S0304-4076(01)00098-7

Maddala, G. S., \& Wu, S. (1999). A comparative study of unit root tests with panel data and a new simple test. Oxford Bulletin of Economics and Statistics, 61(S1), 631-652. https://doi.org/10.1111/1468-0084.61.s1.13

Makrevska-Disovska, E., \& Trpkova-Nestorovska, M. (2016). Factors affecting current account in the Republic of Macedonia. CEA Journal of Economics, 10(2).

Moreno, R. (2007). Experiences with current account deficits in Southeast Asia (Central Bank of Chile working papers No. 452). Chile: Central Bank of Chile.

Mwangi, K. S. (2014). Determinants of current account balance in Kenya (Master's thesis). Kenyatta University, Kenya.

Neaime, S. (2015). Twin deficits and the sustainability of public debt and exchange rate policies in Lebanon. Research in International Business and Finance, 33, 127-143. https://doi.org/10.1016/j.ribaf.2014.09.004

Nieminen, M. (2011). Determinants of current account balances (Master's thesis). University of Jyväskylä, Finland.

Osakwe, P., \& Verick, S. (2007). Current account deficits in Sub-Saharan Africa: Do they matter? United Nations Commission for Africa, 201-220.

Park, D., \& Shin, K. (2009). Savings, investment, and current account surplus in developing Asia (ADB economics working paper series No. 158). Manila, Philippines: Asian Development Bank. https://doi.org/10.2139/ssrn.1611454

Pedroni, P. (1999). Critical values for cointegrationn tests in heterogeneous panels with multiple regressors. Oxford Bulletin of Economics and Statistics, 61(S1), 653-670. https://doi.org/10.1111/1468-0084.61.s1.14

Pedroni, P. (2001). Purchasing power parity tests in cointegrated panels. The Review of Economics and Statistics, 
83(4), 727-731. https://doi.org/10.1162/003465301753237803

Pedroni, P. (2004). Panel cointegration: Asymptotic and finite sample properties of pooled time series tests with an application to the PPP hypothesis. Econometric theory, 20(3), 597-625. https://doi.org/10.1017/S0266466604203073

Phillips, P. C. B. (1995). Fully modified least squares and vector autoregression. Econometrica, 63(5), $1023-1078$. https://doi.org/10.2307/2171721

Phillips, P. C. B., \& Hansen, B. E. (1990). Statistical inference in instrumental variables regression with I(1) processes. Review of Economic Studies, 57(1), 99-125. https://doi.org/10.2307/2297545

Saikkonen, P. (1991). Asymptotically efficient estimation of cointegration regressions. Econometric Theory, 7(1), 1-21. https://doi.org/10.1017/S0266466600004217

Saysombath, P., \& Kyophilavong, P. (2013). Twin deficits in the Lao PDR: An empirical study. International Business and Management, 7(1), 62-68.

World Bank. (2017a). World development indicators. Data center, age dependency ratio for old and young, annual, 1990-2016.

World Bank. (2017b). World development indicators. Data center, GDP, annual, 1990-2016.

\section{Copyrights}

Copyright for this article is retained by the author(s), with first publication rights granted to the journal.

This is an open-access article distributed under the terms and conditions of the Creative Commons Attribution license (http://creativecommons.org/licenses/by/4.0/). 